Dear author,

Please note that changes made in the online proofing system will be added to the article before publication but are not reflected in this PDF.

We also ask that this file not be used for submitting corrections. 


\title{
Mechanical properties of alkali activated ground SiMn slag mortars with different types of aggregates
}

\author{
R. Navarro ${ }^{\text {a }}$, E.G. Alcocel ${ }^{\text {b }}$, I. Sánchez ${ }^{\text {a }}$, P. Garcés ${ }^{\text {a }}$, E. Zornoza ${ }^{\mathrm{a}, *}$ \\ a Dept. of Civil Engineering, University of Alicante, Spain \\ ${ }^{\mathrm{b}}$ Dept. of Architectonic Constructions, University of Alicante, Spain
}

\section{H I G H L I G H T S}

- SiMn slag has been implemented as substrate for alkali activated mortars.

- Two types of alkali activators have been used: waterglass and sodium hydroxide.

- Silica sand, limestone and recycled concrete finer fraction have been used as sand.

- Mortars prepared with silica sand offered the best performance in mechanical tests.

- Recycled sand offered poor strength, due to the absorption of activating solution.

\section{A R T I C L E I N F O}

\section{Article history:}

Received 18 April 2018

Received in revised form 9 July 2018

Accepted 12 July 2018

Available online $\mathrm{xxxx}$

\section{Keywords:}

SiMn slag

Alkali activation

Mortar

Aggregate

\begin{abstract}
A B S T R A C T
This research investigates the mechanical performance and dimensional stability of mortars whose binder is prepared by alkali activation of ground granulated SiMn slag. Two types of activators have been used: $\mathrm{NaOH}$ and waterglass solutions. Three different types of aggregates have been tested: silica sand, limestone sand, and recycled sand obtained from recycled concrete. Three activator concentrations have been adopted in the binder design: 3.0, 3.5 and $4.0 \% \mathrm{Na}_{2} \mathrm{O}$ for $\mathrm{NaOH}$ solution; and 4.0, 4.5 and $5.0 \% \mathrm{Na}_{2} \mathrm{O}$ for waterglass solutions with a constant $\mathrm{SiO}_{2} / \mathrm{Na}_{2} \mathrm{O}$ of 1.0 . The best mechanical performance was obtained for an aggregate/slag ratio of 2/1 when silica sand was used as aggregate: $68 \mathrm{MPa}$ were obtained when waterglass was used as activator, and \% $\mathrm{Na}_{2} \mathrm{O}$ of $4.5-5.0 \%$ at 90 days; $54 \mathrm{MPa}$ were obtained for $\mathrm{NaOH}$ as activator and $4.0 \% \mathrm{Na}_{2} \mathrm{O}$ at 90 days. Limestone sand also offered a good mechanical performance although the maximum compressive strength achieved was about $25 \%$ lower than values obtained with silica sand, but recycled concrete aggregate mortars exhibited poor results, probably due to the high absorption of recycled aggregates. The higher shrinkage was registered in mortars activated with waterglass, although autogenous shrinkage was low for all types of activators and aggregates, except for recycled concrete aggregate.
\end{abstract}

(c) 2018 Published by Elsevier Ltd.

\section{Introduction}

One of the most challenging concerns of our society lays on the environmental problems derived from the actual human activities, specifically those ones associated to our industrial production. In this sense, cement industry has a significant impact in the carbon dioxide emissions which is the main gas responsible of the greenhouse effect and global warming. It is estimated that cement fabrication produces a $6-7 \%$ of total carbon dioxide emissions to the atmosphere [1]. Besides, although this industry efficiency is high, it is also responsible of $2-3 \%$ of the primary energy consumption

\footnotetext{
* Corresponding author.

E-mail address: emilio.zornoza@ua.es (E. Zornoza).
}

in the world [2]. To reduce these levels, the development of new binders with lower environmental hue has gained the attention of many research groups. Additionally the reuse of wastes is a traditional strategy that has been adopted in the last decades and also pursuits the same goal: to obtain construction and building materials that exhibit good performance and durability but spending lower quantities of natural resources [2-4].

In present research, this strategy has been implemented by using an alkali activated binder instead of Portland cement, a waste material as substrate for the preparation of the binder, and also including finer fraction of recycled aggregate as sand in the fabrication of mortars. The waste material whose valorisation is proposed as raw material to design the alkali activated binder is a SiMn slag generated in the production of silico-manganese iron 
alloys. The global production of silico-manganese alloy in year 2016 was 12.5 million tons [5]. Typically the slag generation is about 1.2-1.4 tons for every ton of SiMn alloy produced [6]. Therefore, the slag generated is in the tune of 15.0-17.5 million tons per year, so the amount is high enough to propose its reuse and valorisation. This SiMn slag presents a silico-calcic nature similar to blast furnace slag, but with a different chemical composition: lower content of $\mathrm{CaO}$ and a significantly high proportion of $\mathrm{MnO}$.

Chemical, mineralogical and pozzolanic characteristics presented by the SiMn slag enable its use for obtaining alkali activated materials. Kumar et al. [6] studied the effect of the mechanical activation of the slag in the activation process, and it was evidenced the potential of the SiMn slag to be activated with a sodium hydroxide. Previously to the chemical process, the SiMn slag was treated mechanically by different procedures (ball milling, attrition milling and eccentric vibratory milling). As a result, different particle size distributions and different reactivity due to physicochemical changes in the mass and the surface of the particles were obtained. Their results offered the following performance in the terms of compressive strength of pastes after 28 days of curing time: $24 \mathrm{MPa}$ for ball milling samples, $66 \mathrm{MPa}$ for attrition milling specimens and $101 \mathrm{MPa}$ for vibration milling conditions. Other authors [7] pointed out that the high-energy milling was responsible for achieving this performance and therefore, the environmental benefits were reduced. In another study, air-cooled SiMn slag in combination with fly ash has been used to develop an alkali activated binder, able to react at room temperature with $\mathrm{NaOH}$ as reactant of the alkaline solution [8]. It was concluded that the addition of SiMn slag increased the system reactivity due to the additional contribution to the $\mathrm{CaO}$ content of the mix, so mechanical properties were improved and lower porosity was obtained. However, once again, the main inconvenient was the long milling treatment of the SiMn slag which reduced the environmental benefits of the SiMn slag reuse. Navarro et al. [9] optimized the alkali activation process of the SiMn slag using a solution of waterglass (WG) and the system was evaluated in terms of the mechanical performance, the fluidity and the shrinkage behaviour of pastes. It was concluded that a high enough compressive strength was obtained (over $45 \mathrm{MPa}$ ), but the initial setting time was also very variable (between 38 and $263 \mathrm{~min}$ ) and very high total shrinkage in a 50\% relative humidity $(\mathrm{RH})$ ambient was additionally registered (1.5$3.0 \%)$.

As it has been previously indicated, one of the most explored strategies to reduce the environmental impact of construction and building materials is to reuse industrial by-products. Additionally, the recycling of a wide variety of residues has also been successfully implemented. Previous researches have used the alkali activated systems with different types of recycled aggregates such as waste polyethylene terephthalate (PET) granules [10], cupper slags [11], bottom ash [12], construction and demolition residues [13-15], expanded glass residue [16], crumb rubber from wasted tyres [17], ceramic wastes [18], and some authors have specifically demonstrated a good performance of fine recycled concrete aggregate [19]. The combination of binders made with industrial wastes together with recycled aggregates may produce materials with adequate performance and low demand of natural resources $[18,20]$.
The aim of this research is to evaluate the mechanical performance and dimensional stability of mortars whose binder is prepared by alkali activation of ground granulated SiMn slag using as activator sodium hydroxide and waterglass solutions, and incorporating different types of aggregates: silica sand, limestone sand, and recycled sand obtained from recycled concrete. This study have reported the behaviour of SiMn slag to be used in a wide variety of construction and building materials.

\section{Experimental}

\subsection{Materials}

The substrate for the binder preparation was a ground granulated SiMn slag from the Ferroatlántica plant sited at Boo-deGuarnizo (Cantabria, Spain). Table 1 shows the results of the chemical analysis obtained by X-ray fluorescence in a Philips Magic Pro spectrometer, model PW2400, which is equipped with rhodium tube and beryllium window. The determination was made using a pill sample under vacuum conditions. According to previous works [9] the slag basicity index is 0.73 and hydraulicity index is 0.85 , so this residue can be classified as an acid slag with moderate hydraulicity [21-23].

The determination of the vitreous phase content by X-ray diffraction has been performed in a PANalytical diffractometer, model EMPYREAN. The complete identification and quantification have been determined by Rietveld method [24] using quartz as standard sample, $\mathrm{MoK}_{\alpha 1}$ radiation, a scan from 3 to 35 degrees (20), for $5 \mathrm{~h}$ in 0.0113 degrees steps, at $50 \mathrm{kV}$ and $50 \mathrm{~mA}$. The resulting vitreous content of the slag was $96.0 \pm 1.5 \%$.

The determination of reactive silica and insoluble residue of the SiMn slag was made according to standards UNE 80225-2012 and UNE 196-2-2014 [25,26]. The results provided a $3.35 \%$ of insoluble residue and a $33.80 \%$ of reactive silica.

According to the slag chemical composition, its reactive silica content and its vitreous phase proportion, the alkali activation procedure should be successfully implemented on this materials, which is also in accordance with previous studies [9,22,27].

The granulated SiMn slag was ground in dry conditions using a laboratory ball mill Nanneti model SPEEDY 1 for $25 \mathrm{~min}$. The fineness of the resulting ground slag was determined by the Blaine's air permeability method [28], a value of $5512 \mathrm{~cm}^{2} / \mathrm{g}$ was obtained, which lays in the optimal range established by previous authors who concluded that the optimal fineness for acid slags similar to the one investigated in present research is in the range of 4500$6000 \mathrm{~cm}^{2} / \mathrm{g}$ [23]. Additionally, the particle size distribution of the slag has been measured by a laser diffraction equipment, using a Malvern Instruments, model Mastersizer 2000. The characteristic parameters resulting from this analysis were $\mathrm{D}_{\mathrm{V}, 50}=9.2 \mu \mathrm{m}$ and $D_{4,3}=15.2 \mu \mathrm{m}$. The $D_{V, 50}$ is the size in microns that splits the volume distribution with half above and half below this diameter. The $\mathrm{D}_{4,3}$ is the volume mean diameter.

Alkaline solutions used to activate the SiMn slag were prepared with a commercial sodium silicate $\left(\mathrm{Na}_{2} \mathrm{SiO}_{3}\right.$ (neutral solution $\mathrm{QP}$, Panreac): $\mathrm{SiO}_{2} / \mathrm{Na}_{2} \mathrm{O}$ molar ratio $=3.28$ ) and sodium hydroxide (technical grade, Panreac). Two different types of activators and three different activator concentrations have been tested in the

Table 1

Composition of the SiMn slag determined by X-ray fluorescence analysis.

\begin{tabular}{|c|c|c|c|c|c|c|c|c|c|c|c|}
\hline Component & $\mathrm{SiO}_{2}$ & $\mathrm{CaO}$ & $\mathrm{MnO}$ & $\mathrm{Al}_{2} \mathrm{O}_{3}$ & $\mathrm{MgO}$ & $\mathrm{Fe}_{2} \mathrm{O}_{3}$ & $\mathrm{~K}_{2} \mathrm{O}$ & $\mathrm{Na}_{2} \mathrm{O}$ & $\mathrm{SO}_{3}$ & N.D & L.O.I $^{* *}$ \\
\hline Mass $\%$ as oxide & 36.53 & 29.10 & 12.23 & 9.86 & 4.69 & 0.92 & 1.08 & 0.34 & 2.77 & 2.48 & -1.25 \\
\hline
\end{tabular}

N.D.: Not determined.

L.O.I.: Loss on ignition at $950{ }^{\circ} \mathrm{C}$ for $1 \mathrm{~h}$. 
experimental campaign: $\mathrm{NaOH}$ solution with a $3.0 \%, 3.5 \%$ and $4.0 \%$ of $\mathrm{Na}_{2} \mathrm{O}$; and a waterglass solution (WG) with a $4.0 \%, 4.5 \%$ and $5.0 \%$ of $\mathrm{Na}_{2} \mathrm{O}$. $\mathrm{NaOH}$ activating solutions was prepared by solving the required amount of sodium hydroxide in distilled water. WG solution was fabricated by mixing sodium silicate and sodium hydroxide in the appropriate quantities and the subsequent dilution of the mix with distilled water. The $\mathrm{SiO}_{2} / \mathrm{Na}_{2} \mathrm{O}$ ratio of the WG solution was set to 1.00 . These activating solutions were selected according to the particular findings of a previous research [9].

Three different types of fine aggregate were used to prepare the mortars: silica sand, limestone sand and recycled sand coming from the finer fraction of ground recycled concrete. All types of sand were in accordance with the particle size distribution required for mortar preparation according to E.M. de Fomento (2010) [29]. Fig. 1 presents the particle size distribution of the aggregates used in present research together with the limits required. Although all of them accomplish the requirements, there exist differences in term of their fineness and the content of particles under $63 \mu \mathrm{m}$ that would explain their different influence on other properties of the prepared mortars. Table 2 presents some physical properties of the aggregates. Fineness modulus (FM) was calculated according to UNE 146301:2002 [30], and water absorption and density were calculated according UNE-EN 1097:6/ A1:2014 [31].

\subsection{Sample preparation and tests}

Mortars were prepared with ground granulated SiMn slag, sand and the calculated quantity of alkaline solutions. Samples were prepared in a mixer Controls Automix, model 65-L0006/A for 4 min according to UNE EN 196-1 [32]. Four design variables in the mortar dosage were considered: aggregate/slag ratio, type of aggregate, type of activator and activator concentration $\left(\% \mathrm{Na}_{2} \mathrm{O}\right)$. Fig. 2 shows a scheme of the dosages prepared in present research. As a result, 24 different mortars were fabricated to evaluate the

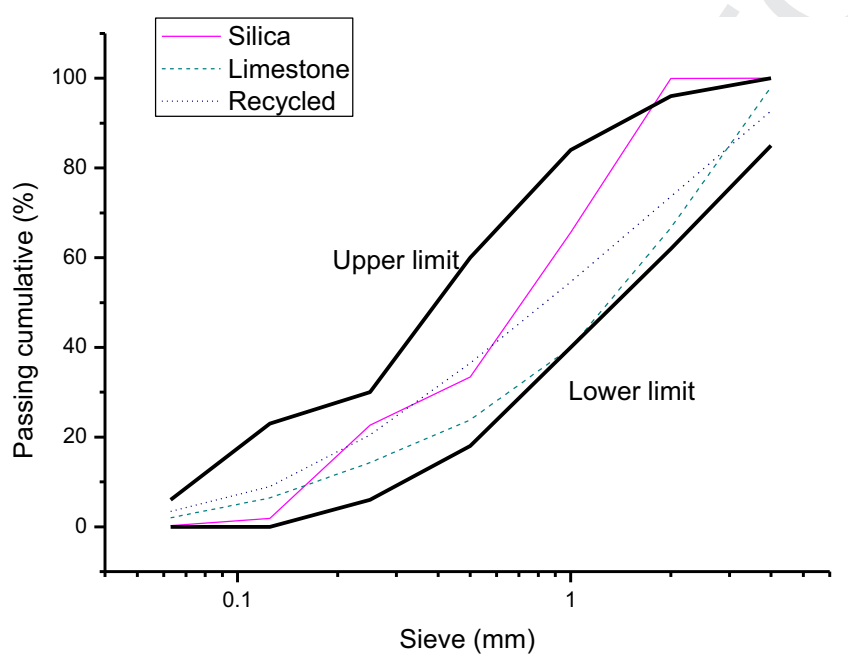

Fig. 1. Particle size distribution of the aggregates.

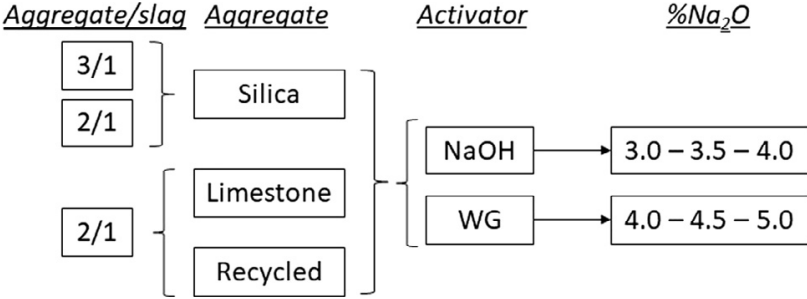

Fig. 2. Scheme of the dosages adopted for the experimental procedure.

influence of these four design variables on mechanical properties and shrinkage behaviour.

Mortar workability (slump test): Mortar workability was determined with the slump test according to UNE 1015-3 [33]. The mortar diameter was measured in four directions and the arithmetic mean taken as the final value.

Flexural strength: Three $40 \times 40 \times 160 \mathrm{~mm}$ specimens for each mix were fabricated to test flexural strength. The samples were cured in $100 \% \mathrm{RH}$ for 7,28 and 90 days at $20 \pm 2{ }^{\circ} \mathrm{C}$ and then tested using a hydraulic press following the standard EN 196-1 [32]. Each flexural strength value was obtained from the average value of the three tests.

Compressive strength: Six $40 \times 40 \times \approx 40 \mathrm{~mm}$ specimens for each mix given in the experimental work plan were tested on compressive strength. The samples were taken from the two resulting parts of a specimen previously broken in the flexural strength test. In that sense, specimens had been cured in $100 \%$ RH for 7,28 and 90 days at $20 \pm 2202 \mathrm{Fb} 0 \mathrm{C}$ and then tested using a hydraulic press following the standard EN 196-1 [32]. Each compressive strength value was obtained from the average value of the six tests.

Shrinkage: Shrinkage of hardened mortars was tested following the Spanish standard UNE 80112 [34]. Four prismatic mortar specimens measuring $285 \times 25 \times 25 \mathrm{~mm}$ were prepared for each mix given in the experimental work plan. Two different storage conditions were applied to the fabricated mortars: two specimens were subjected to a $100 \%$ RH to monitor the evolution of the autogenous shrinkage and the other two specimens were stored at 50\% RH to register the autogenous and drying shrinkage. Drying shrinkage was determined by the difference between the relative deformation at $50 \% \mathrm{RH}$ and $100 \% \mathrm{RH}$. The presented results are the average value of two specimens.

Mercury intrusion porosimetry: The pore size distribution of mortars was determined by mercury intrusion porosimetry technique. Both the total connected porosity and the pore size distribution in the $0.0035-250 \mu \mathrm{m}$ diameter range were obtained. An Autopore IV 9500 Micromeritics mercury porosimeter was used. The Hg pressure range was $0.5-33,000$ psi $(0.015-205 \mathrm{MPa})$.

\section{Results and discussion}

\subsection{Fluidity and workability tests}

In order to obtain a material suitable to be used in real applications, the first goal of this investigation was to establish a proper fluidity and workability time. With this aim, the samples should provide a minimum slump of $160 \mathrm{~mm}$ after $40 \mathrm{~min}$ from their

Table 2

Physical characteristics of the aggregates.

\begin{tabular}{lllll}
\hline Type of aggregate & Fraction under $63 \mu \mathrm{m} \mathrm{( \% )}$ & Fineness modulus & Density $\left(\mathrm{g} / \mathrm{cm}^{3}\right)$ & Water absorption $(\%)$ \\
\hline Silica & $<0.1$ & 3.8 & 2.5 & 0.2 \\
Limestone & 2.0 & 4.5 & 2.6 & 1.7 \\
Recycled & 3.4 & 4.1 & 2.4 & 6.6 \\
\hline
\end{tabular}


preparation. Several s/s ratios were tested for each aggregate, type of activator and aggregate/slag ratio. Table 3 presents the selected $\mathrm{s} / \mathrm{s}$ ratio which accomplished the imposed requirements and Fig. 3 shows the evolution of slump in the selected samples. These results were obtained with the lower concentration of $\mathrm{Na}_{2} \mathrm{O}$ for each type of activator. It was checked that the slumps were not significantly affected within the $\% \mathrm{Na}_{2} \mathrm{O}$ range used in this work. However, for high $\% \mathrm{Na}_{2} \mathrm{O}$, the setting process of the slag was more rapid accordingly to other authors' results [23]. On the other hand, in general terms, it was observed that the use of WG implied higher initial mortar fluidity but it decreased more quickly than for mortars prepared with $\mathrm{NaOH}$. This trend has been previously reported and it is explained by the influence of the anion of the activation solution, which is responsible of the setting evolution, and being the silicate a setting accelerator [35-37]. For that reason, mortars activated with $\mathrm{NaOH}$ required lower s/s ratio to achieve the established workability. As general trend, it can be noted that an increase in the aggregate/slag ratio required an increase in the s/ $\mathrm{s}$ ratio, which is expectable since the amount of solid particle to lubricate is higher in mortar with higher proportion of sand. On the other hand, the amount of activating solution required is related to the aggregate type. It was observed that recycled aggregate needed the highest $\mathrm{s} / \mathrm{s}$ ratio, whereas the silica sand required the lower one. Once again, the explanation is found in the specific surface to be wet for each type of aggregate. In this case, the proportion of small particles (under $63 \mu \mathrm{m}$ ) determines significant differences in the solution demand. As it can be observed in Table 2, the aggregate with higher level of particles under $63 \mu \mathrm{m}$ is recycled aggregate, and the aggregate with lower quantity of particles in this range is silica sand. This tendency is consistent with both types of activating solution. In addition, in Table 2, it can be also appreciated that the water absorption of each type of aggregate is in accordance with the solution/slag ratio required to achieve the desired workability. It should be noted the very high water absorption of the recycled concrete aggregate which is due to the mortar included in that type of aggregate, whose own porosity would act as a significant water (or activating solution) absorbent.

\subsection{Pore size distributions of mortars}

Total porosity of alkali activated SiMn mortars after 90 days of curing time are presented in Fig. 4. The selection of mortars have been done according to general mechanical performance criteria. Although it will be discussed later, the higher compressive strength was obtained, in general terms, by mortars with higher activator concentration, i.e. $4.0 \% \mathrm{Na}_{2} \mathrm{O}$ in the case of $\mathrm{NaOH}$, and $5.0 \% \mathrm{Na}_{2} \mathrm{O}$ for WG. In Fig. 4, it can be observed that mortars prepared with $\mathrm{NaOH}$ showed higher porosity within the pore range of the technique used (from $0.0035 \mu \mathrm{m}$ to $250 \mu \mathrm{m}$ ) than mortars activated with WG, which is in accordance to previous studies [38]. With regards to the influence of the type of aggregate, these results

Table 3

Summary of the selected $\mathrm{s} / \mathrm{s}$ ratio which provided a minimum slump of $160 \mathrm{~mm}$ after $40 \mathrm{~min}$.

\begin{tabular}{llll}
\hline $\begin{array}{l}\text { Type of } \\
\text { activator }\end{array}$ & $\begin{array}{l}\text { Type of } \\
\text { aggregate }\end{array}$ & $\begin{array}{l}\text { Aggregate/slag } \\
\text { ratio }\end{array}$ & $\begin{array}{l}\text { Selected s/s } \\
\text { ratio }\end{array}$ \\
\hline $\mathrm{NaOH}$ & Silica & 3 & 0.47 \\
& Silica & 2 & 0.37 \\
& Limestone & 2 & 0.45 \\
& Recycled & 2 & 0.53 \\
$\mathrm{WG}$ & Silica & 3 & 0.50 \\
& Silica & 2 & 0.40 \\
& Limestone & 2 & 0.47 \\
& Recycled & 2 & 0.53
\end{tabular}

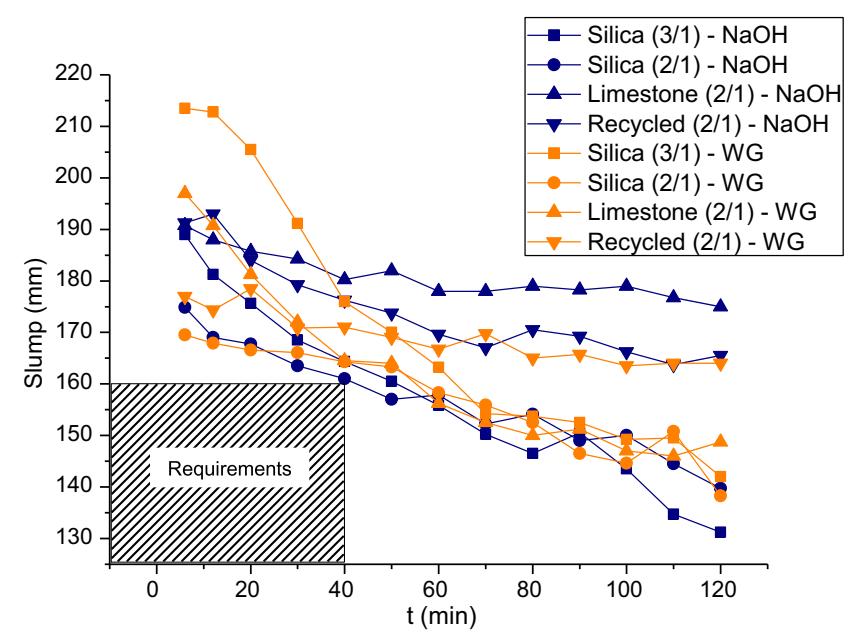

Fig. 3. Evolution of slump of different samples after their preparation. Activator concentration is $3.0 \% \mathrm{Na}_{2} \mathrm{O}$ for $\mathrm{NaOH}$ and $4.0 \% \mathrm{Na}_{2} \mathrm{O}$ for WG.

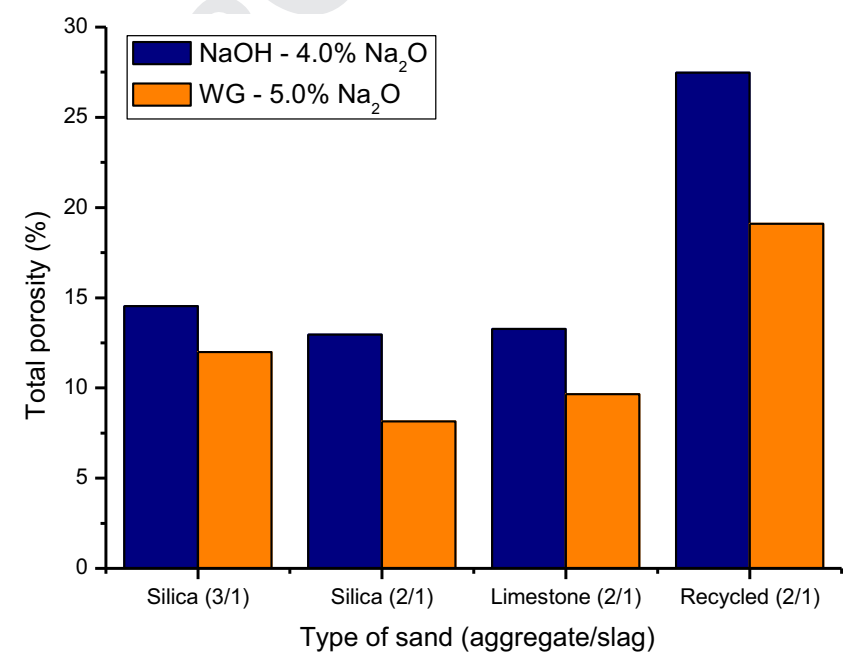

Fig. 4. Total porosity of selected alkali activated SiMn slag mortars after 90 days of curing time.

agree with the granulometric characteristics of each aggregate and consequently with the different demand of activating solution needed to achieve the required workability, which directly determines their final porosity. It can be noted that mortars with silica sand with an aggregate/slag ratio of $2 / 1$ exhibited the lower total porosity. Mortars with limestone sand and aggregate/slag ratio of 2/1 presented slightly higher porosity than mortars with silica sand and the same aggregate proportion. Both of them were closely followed by mortar with silica sand but aggregate/slag ratio of 3/1. Finally, the most remarkable evidence was the very high porosity presented by mortar prepared with recycled concrete aggregate, which was approximately double the porosity offered by the rest of the mortars. Obviously, part of the porosity increase of the mortar fabricated with recycled aggregate is due to the old mortar included in the aggregate. Besides, the higher porosity of mortar with silica sand an aggregate/slag ratio of $3 / 1$ respect to those with ratio $2 / 1$ is due to the lower quantity of binder paste able to fill the pores and the higher quantity of aggregate which implies a higher demand of activating solution to obtain the desired workability. This fact will produce lower mechanical strength of mortars with higher aggregate/slag ratio since, in alkali activated systems, which do not generate hydrated products, an excessive $\mathrm{s} / \mathrm{s}$ ratio leads to a high porosity that will not decrease with time [39]. 
Fig. 5 shows pore size distributions of selected alkali activated SiMn slag mortars after 90 days of curing time. As it can be observed, most of the porosity volume is located in pores with diameter lower than $0.1 \mu \mathrm{m}$. In addition, in general terms, mortars including recycled concrete aggregate exhibit larger porosity volume in almost any porosity range, although the most evident difference appears in the lower porosity interval, where mortars with recycled aggregated presents double the volume of porosity than the rest of mortars. Minor differences are observed among the rest of mortars.

\subsection{Mechanical properties}

Fig. 6 presents flexural strength results of alkali activated SiMn slag mortars with silica sand, two aggregate/slag ratios and both activators at different curing ages. The main observation that can be stated is the best performance offered by mortars with an aggregate/slag ratio of $2 / 1$. The reason for this behaviour may be found in the modifications introduced by the change in the proportion of aggregate $[40,41]$. Those mortars with higher proportion of sand would produce a lower amount of activated paste, i.e. SiMn slag plus alkaline solution, that is available to give cohesion to the aggregates. Besides, they will require higher s/s and thus higher porosity would be produce in those mortars. This behaviour is more evident for those mortars where WG has been used as activator, in which negligible flexural strength was detected for mortars with the lower $\% \mathrm{Na}_{2} \mathrm{O}$ at any age. Besides, other problems presented by mortars with higher aggregate/slag ratio was the decrease of flexural strength at 90 days of curing age recorded for mortars activated with $\mathrm{NaOH}$. Regarding the influence of \% $\mathrm{Na}_{2} \mathrm{O}$ on the flexural strength, the best performance was obtained for the higher concentration (4.0\%) in the case of $\mathrm{NaOH}$ and the intermediate concentration (4.5\%) for WG when the aggregate/slag ratio was $2 / 1$. For mortars with the higher aggregate/slag ratio $(3 / 1)$, the best results were shifted to higher $\% \mathrm{Na}_{2} \mathrm{O}$ for both activators. That would support the arguments about the effect of sand proportions pointed out before, since the effective activator concentration for these mortars would be lower than the activator concentration of mortars with aggregate/slag ratio of $2 / 1$. In terms of the influence of the activator type, and observing the results belonging to the lower aggregate/slag ratio, which were more consistent, it was noticed that $\mathrm{NaOH}$ showed higher flexural strength at early ages ( 7 days). At 28 days of curing time, both activators offered similar results and WG behaved better at 90 days of curing time. The higher flexural strength was achieved by silica sand mortar with aggregate/slag ratio of $2 / 1$, WG as activator and $4.5 \%$ of $\mathrm{Na}_{2} \mathrm{O}$ at 90 days of curing time, which offered 9.0 MPa. In the case of using $\mathrm{NaOH}$ as activator the best result was obtained by the mortar with an aggregate/slag ratio of $2 / 1$, and $4.0 \%$ of $\mathrm{Na}_{2} \mathrm{O}$, which registered $8.0 \mathrm{MPa}$ at 28 days of curing time.

Compressive strength values offered by alkali activated SiMn slag mortars with silica sand and two aggregate/slag ratios and both activators at different curing ages are presented in Fig. 7. As it was previously pointed out, the best performance was achieved by mortars with lower aggregate content. Once again, mortars prepared with WG were more sensitive to the detrimental effect of higher aggregate/slag ratio. These results agree with previous researches made on pastes [9], although the presence of the aggregate, in this case, seems to delay the strength gain. With regards to the influence of activator type, the WG clearly offered higher compressive strength than $\mathrm{NaOH}$, especially at longer curing times as it was expected $[23,35]$. As it has been previously reported, mortars prepared with WG required higher $s / s$, but the total porosity that they exhibited was lower and the mechanical performance was better, which is due to the main role played by the silicate anion in the activation process. Silicate anion accelerated the setting, so higher s/s had to be used in order to achieve the desired workability. Besides, an enhanced contribution to the C-A-S-H gel formation was derived and thus the microstructure would be densified and the mechanical strengths improved. An exception to this can be found in mortars with WG, aggregate/slag ratio of 3/1 and low \% $\mathrm{Na}_{2} \mathrm{O}$, whose results were lower at any curing age since two negative effects merge for them: a low activator concentration, and the increase in the pore volume due to the high s/s ratio [23]. The best value of compressive strength was achieved by mortars with aggregate/slag ratio of $2 / 1$, WG as activator, and $\% \mathrm{Na}_{2} \mathrm{O}$ of $4.5 \%$ $5.0 \%$ at 90 days; these mortars offered $68 \mathrm{MPa}$. In the case of using $\mathrm{NaOH}$ as activator, the higher compressive strength was reached by a mortar with aggregate/slag ratio of $2 / 1$ and $4.0 \%$ of $\mathrm{Na}_{2} \mathrm{O}$ content at 90 days; a value of $54 \mathrm{MPa}$ was obtained.

Once it has been clearly shown that the increase in the aggregate content would lead to a decrease in the mechanical performance, only the lower aggregate/slag ratio was used with the other two types of aggregates, i.e. limestone sand and recycled concrete aggregate. Fig. 8 shows flexural strength results of alkali activated SiMn slag mortars with an aggregate/slag ratio of 2/1 and two different aggregates (limestone and recycled sand) and both activators at different curing ages. The most evident observa-

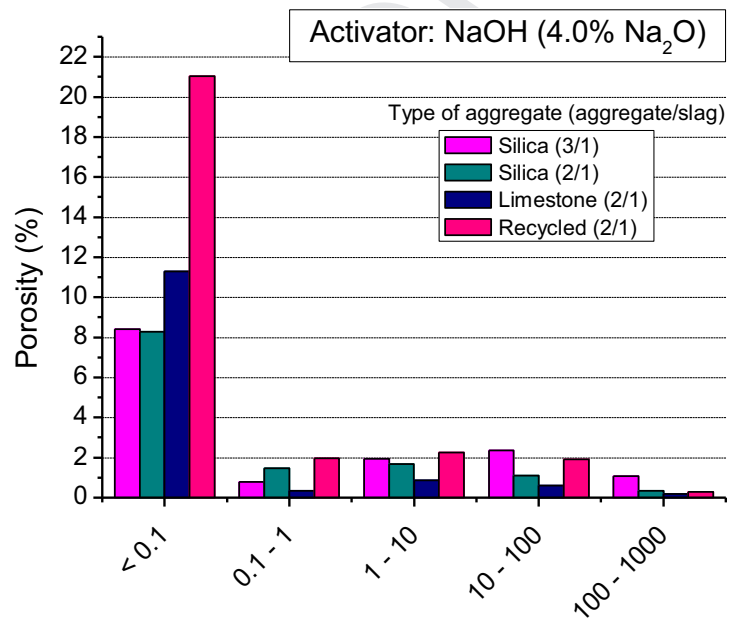

Pore diameter range $(\mu \mathrm{m})$

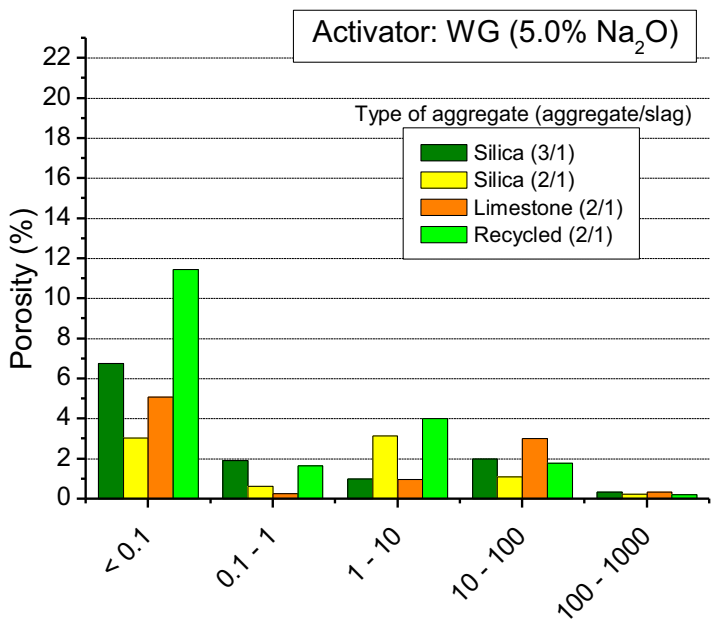

Pore diameter range $(\mu \mathrm{m})$

Fig. 5. Pore size distributions of selected alkali activated SiMn slag mortars after 90 days of curing time. 

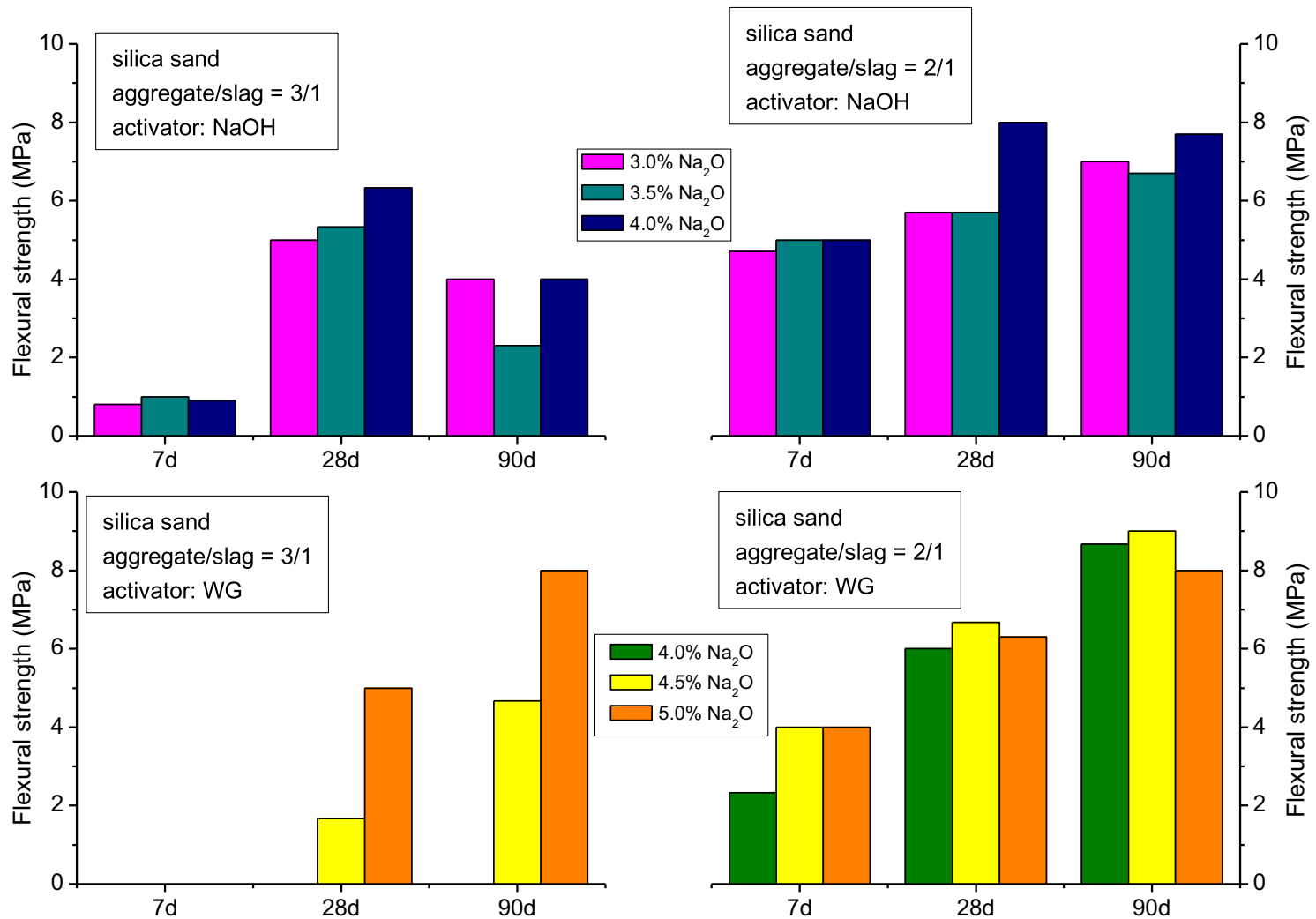

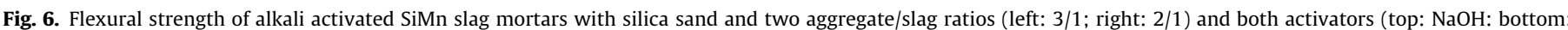
WG) at different curing ages.
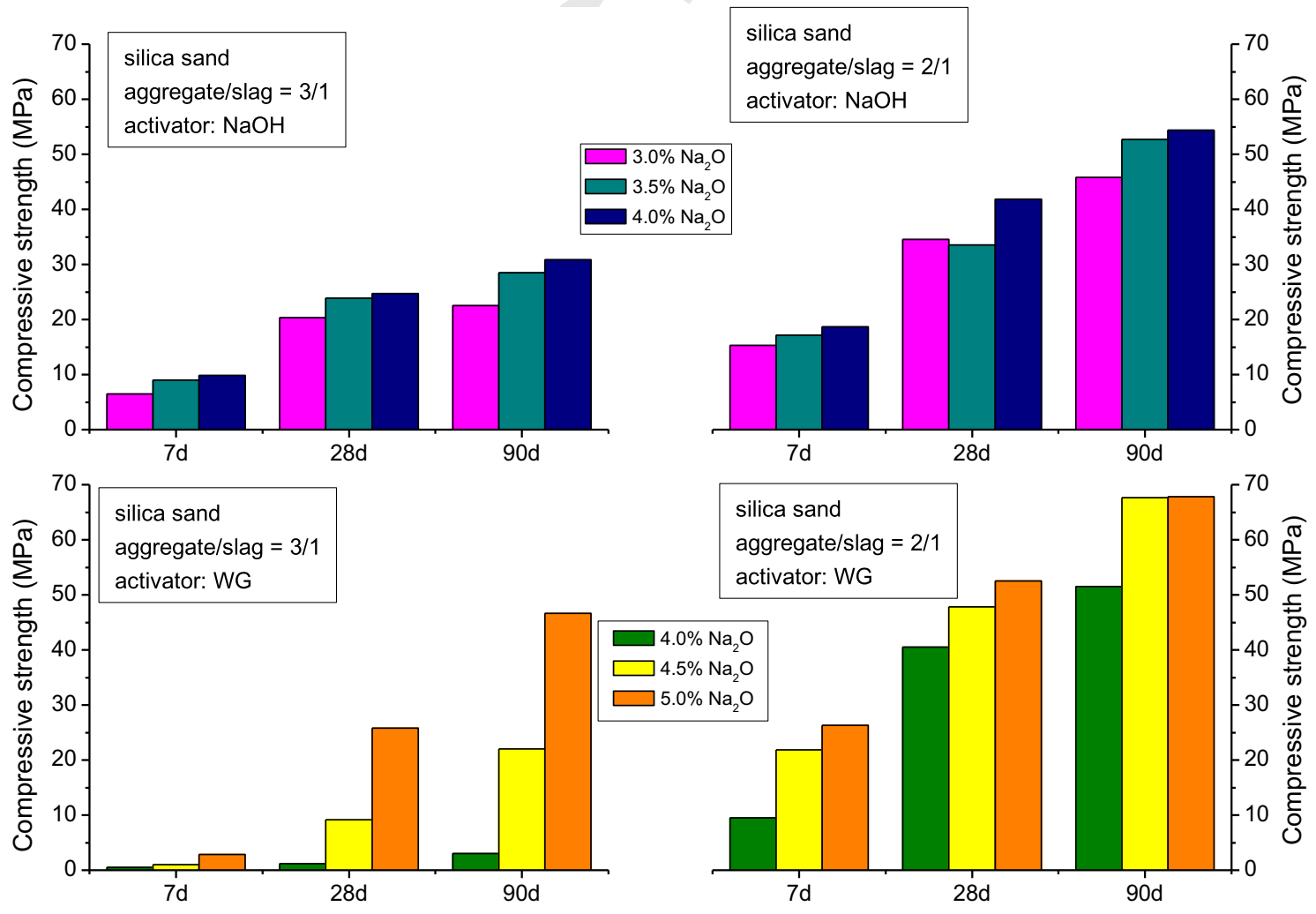

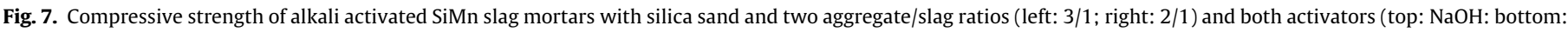
WG) at different curing ages.

Please cite this article in press as: R. Navarro et al., Mechanical properties of alkali activated ground SiMn slag mortars with different types of aggregates, Constr. Build. Mater. (2018), https://doi.org/10.1016/j.conbuildmat.2018.07.093 

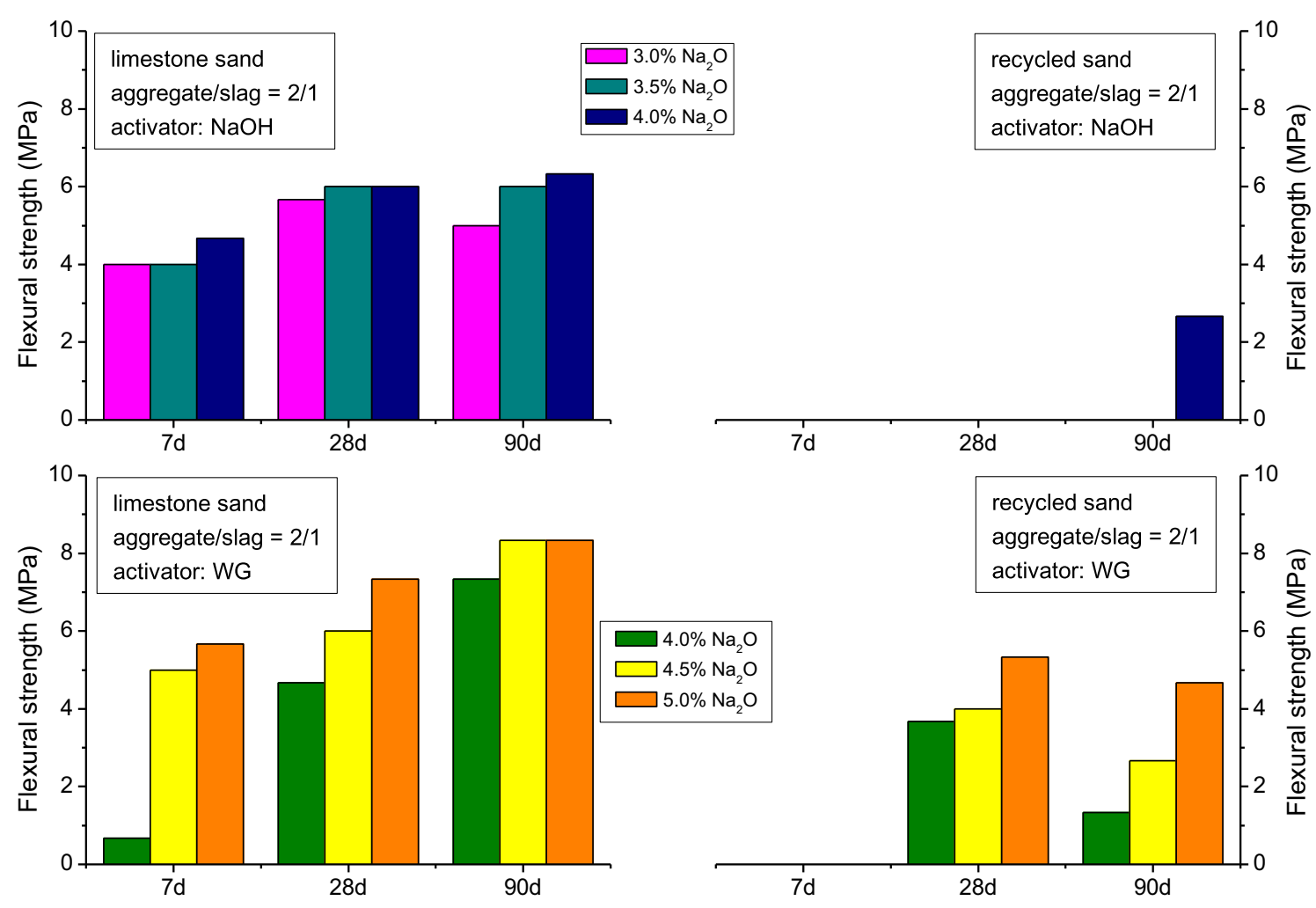

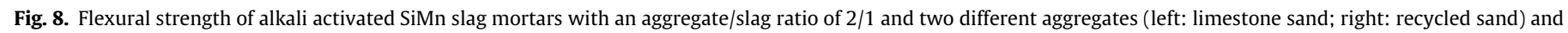
both activators (top: $\mathrm{NaOH}$ : bottom: WG) at different curing ages.

tion is the poor performance offered by recycled aggregate. Flexural strength of mortars containing recycled aggregate was negligible at any curing age when $\mathrm{NaOH}$ was used as activator: only a value of 2.5 MPa could be registered by the mortar with the higher activator concentration at 90 days of curing age. If WG was used as activator for mortars prepared with recycled aggregate, moderate flexural strength values were obtained at 28 days of curing time (4-5.5 MPa), but a decrease of them was observed at 90 days of curing time. A similar effect was observed for mortars with $\mathrm{NaOH}$, aggregate/slag = 3/1 and silica sand. A hypothesis to explain the poor performance of recycled concrete aggregate mortars could be found on the physical characteristics of this particular aggregate. As it can be observed in Table 2, the water absorption capacity of recycled aggregate is much higher than those registered for the other fine aggregates (6.58\% vs $1.74 \%$ and $0.21 \%)$. This characteristic imposed the use of a higher solution to slag ratio (see Table 3) with the aim of obtaining the required workability of mortars, and it would have an impact in the final density and porosity of mortars, which is in agreement with the results provided by Figs. 4 and 5.

The other natural aggregate, i.e. limestone sand, behaved similarly to silica sand, although the flexural strength values that they offered were not so high. In this case, the best $\mathrm{Na}_{2} \mathrm{O}$ contents were the highest for both activators (4.0\% for $\mathrm{NaOH}$ and $5.0 \%$ for WG) and, in general, WG was again the best activator in terms of its performance in flexural strength. Besides, all mortar prepared with limestone sand increased their flexural strength with time. The higher flexural strength was obtained by mortars with WG as activator and $4.5-5.0 \%$ of $\mathrm{Na}_{2} \mathrm{O}$ at 90 days of curing time, which offered $8.3 \mathrm{MPa}$. In the case of using $\mathrm{NaOH}$ as activator the best result was obtained by the mortar with $4.0 \%$ of $\mathrm{Na}_{2} \mathrm{O}$, which registered 6.3 MPa at 90 days of curing time. These values are $8 \%$ and $21 \%$ lower than the best flexural strength results obtained by silica sand mortars and WG and $\mathrm{NaOH}$, respectively. The lower performance of this type of aggregate may be supported by the lower physical characteristics of the limestone aggregate, which offered higher water absorption capacity that implied to increase the amount of solution to be used in the mix. Again these results are coherent with the registered porosity of those mortars.

Fig. 9 presents compressive strength results of alkali activated SiMn slag mortars with an aggregate/slag ratio of $2 / 1$ and two different aggregates (limestone sand and recycled concrete sand) and both activators at different curing ages. The same behaviour observed in these mortars in terms of their flexural strength can be appreciated in the case of their compressive strength. Mortars that included recycled sand offered a limited development of compressive strength. This results could be expected according to the absorption of the activating solutions that can occurs due to the porosity of the old mortar included in the recycled concrete aggregate [42], although there is not a general consensus about the effect of recycled aggregates on alkali activated systems. In some cases no differences were observed in compressive strengths of concretes made with alkali activated slag in the case of a total natural coarse aggregate replacement by recycled concrete aggregate $[43,44]$. On the other hand, other studies made on alkali activated fly ash concrete showed a decrease of compressive strength when a $50 \%$ of natural coarse aggregate was replaced by recycled aggregate $[15,45]$. In present research a clear detrimental effect of the recycled aggregate can be reported. A clear relationship between $\mathrm{Na}_{2} \mathrm{O}$ concentration and compressive strength was observed: the highest the $\mathrm{Na}_{2} \mathrm{O}$ content, the highest the compressive strength that is registered for both activators and both types of sand, which is good agreement with previous studies [23,35]. Also, as it should be expected, mortars gained strength with curing time in any case. Comparing the influence of the activator type, it can be observed again that WG is more sensitive to the activator concentration 

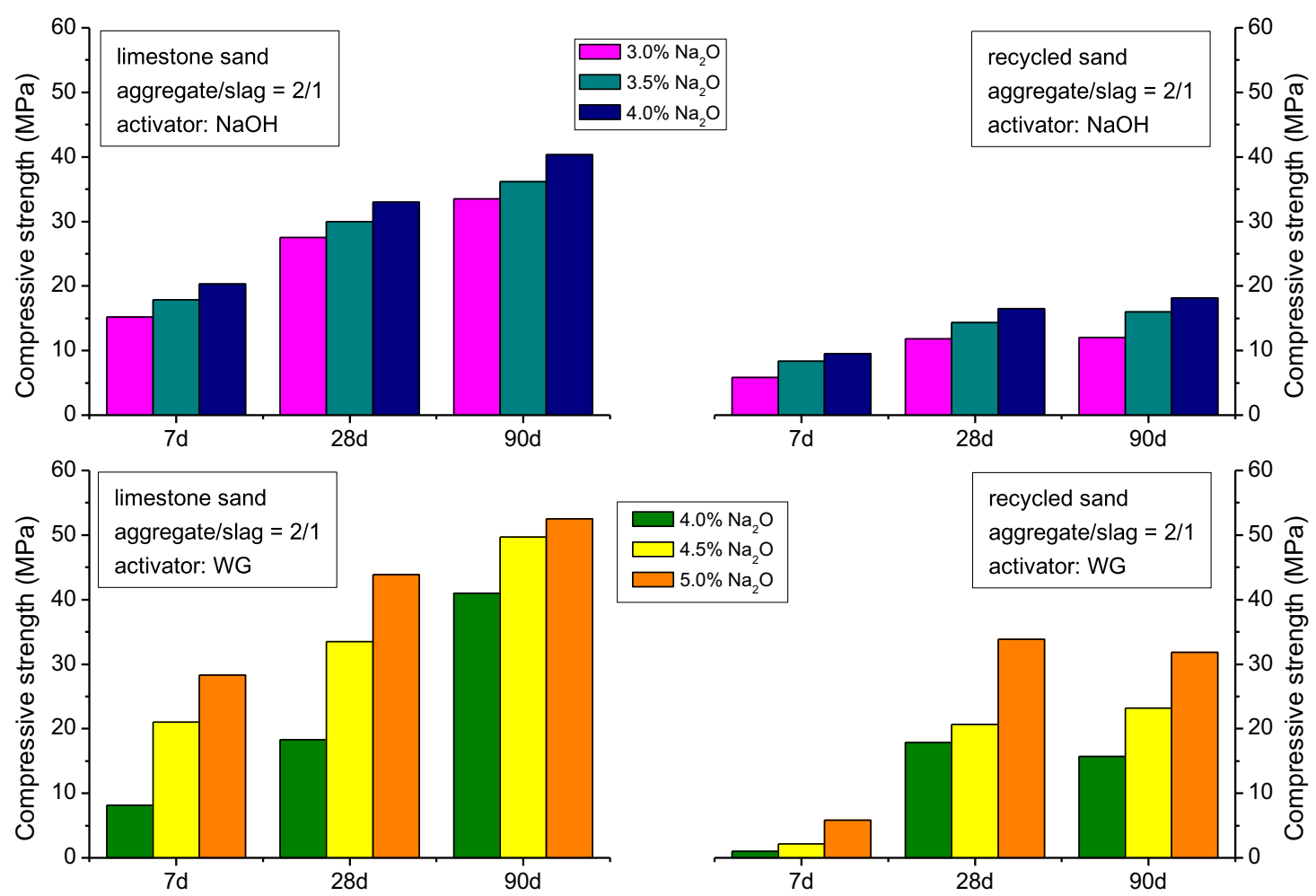

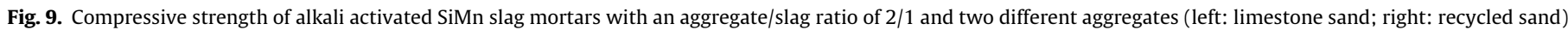
and both activators (top: $\mathrm{NaOH}$ : bottom: WG) at different curing ages.

and also WG behaves better than $\mathrm{NaOH}$ in general terms, especially at longer curing times as it was previously stated by other authors [35]. The best records of compressive strength achieved by mortars with WG as activator were obtained for $\% \mathrm{Na}_{2} \mathrm{O}$ of $5.0 \%$ at 90 days; these mortars offered $52 \mathrm{MPa}$ for limestone sand mortars and 32 MPa for recycled sand mortars, which implies a $24 \%$ and $53 \%$ lower than the equivalent silica sand mortar, respectively. In the case of using $\mathrm{NaOH}$ as activator, the higher compressive strengths were achieved by mortars with $4.0 \%$ of $\mathrm{Na}_{2} \mathrm{O}$ content at 90 days; values of $40 \mathrm{MPa}$ for limestone sand mortars and $18 \mathrm{MPa}$ for recycled concrete sand were registered, which implies a decrease of $26 \%$ and $67 \%$ respect to equivalent silica sand mortars, respectively.

With regards to the influence of sand type in the mortar behaviour, it can be observed, as it is expected, a clear influence on the mechanical strength of both the mineralogical origin and the particle size distribution. The higher hardness of silica sand in junction to its lower absorption and lower finer fraction content, explain the higher mechanical strength obtained.

\subsection{Shrinkage evolution}

Fig. 10 shows an example of deformation evolution to observe the typical shrinkage behaviour of alkali activated SiMn slag mortars. With this aim, only mortars with silica sand and aggregate to slag ratio of 2/1 are depicted, although the rest of mortars prepared with the other fine aggregates or aggregate to slag ratio presented similar evolutions. Different storage conditions were used to determine different origin shrinkage. A set of mortars was stored in $100 \% \mathrm{RH}$ to monitor autogenous shrinkage (Fig. 10 top), and another set was stored in 50\% RH ambient to register joint autogenous and drying shrinkage (Fig. 10 middle). The difference between the deformations registered in both conditions was used to determine the drying shrinkage (Fig. 10 bottom). From Fig. 10, it can be observed that dimensional stability is achieved earlier for mortars activated with WG in dry conditions (50\% RH), which did not experienced significant length changes after 20 days. Mortars prepared with $\mathrm{NaOH}$ had to wait almost 50 days to stabilize their length. In general, mortars prepared with WG presented higher total shrinkage than those ones prepared with $\mathrm{NaOH}$, as it was expected according to previous references $[35,38,46]$.

Fig. 11 presents autogenous and drying shrinkage of alkali activated SiMn slag mortars with different types of aggregates and activators. These values have been calculated as the average of the last four values registered for each mortar mix. In general terms, mortars which were activated with $\mathrm{NaOH}$ presented lower autogenous and drying shrinkage. This observation could be opposed to the higher porosity presented by $\mathrm{NaOH}$-activated mortars, but it should be considered that WG-activated SiMn slag binders would have a significant volume of porosity below the limit of detection of conventional mercury intrusion porosimeter. In fact, the lower the diameter of pore, the higher the capillary forces that produce shrinkage. For this reason, mortars activated with WG, which would have a part of their porosity in the lower range would exhibit higher shrinkage. To support this argument Fig. 12 presents the pore size distributions of alkali activated SiMn slag pastes at 28 days of curing in $100 \% \mathrm{RH}$ ambient. It can be deduced that in pastes activated with WG, a wide portion of the binder porosity is located below the detection limit of the mercury intrusion porosimeter.

Regarding the magnitude of the both types of shrinkage, it can be noticed that drying shrinkage is more significant that autogenous shrinkage, except for mortars prepared with recycled concrete aggregate which show similar contributions of both types of shrinkage, independent of the type of activator.

The type of aggregate also plays a similar role independently of the type of activator but in a different extent. When $\mathrm{NaOH}$ was used as activator, mortars with recycled concrete aggregate offered the highest autogenous shrinkage, and mortars with silica sand 

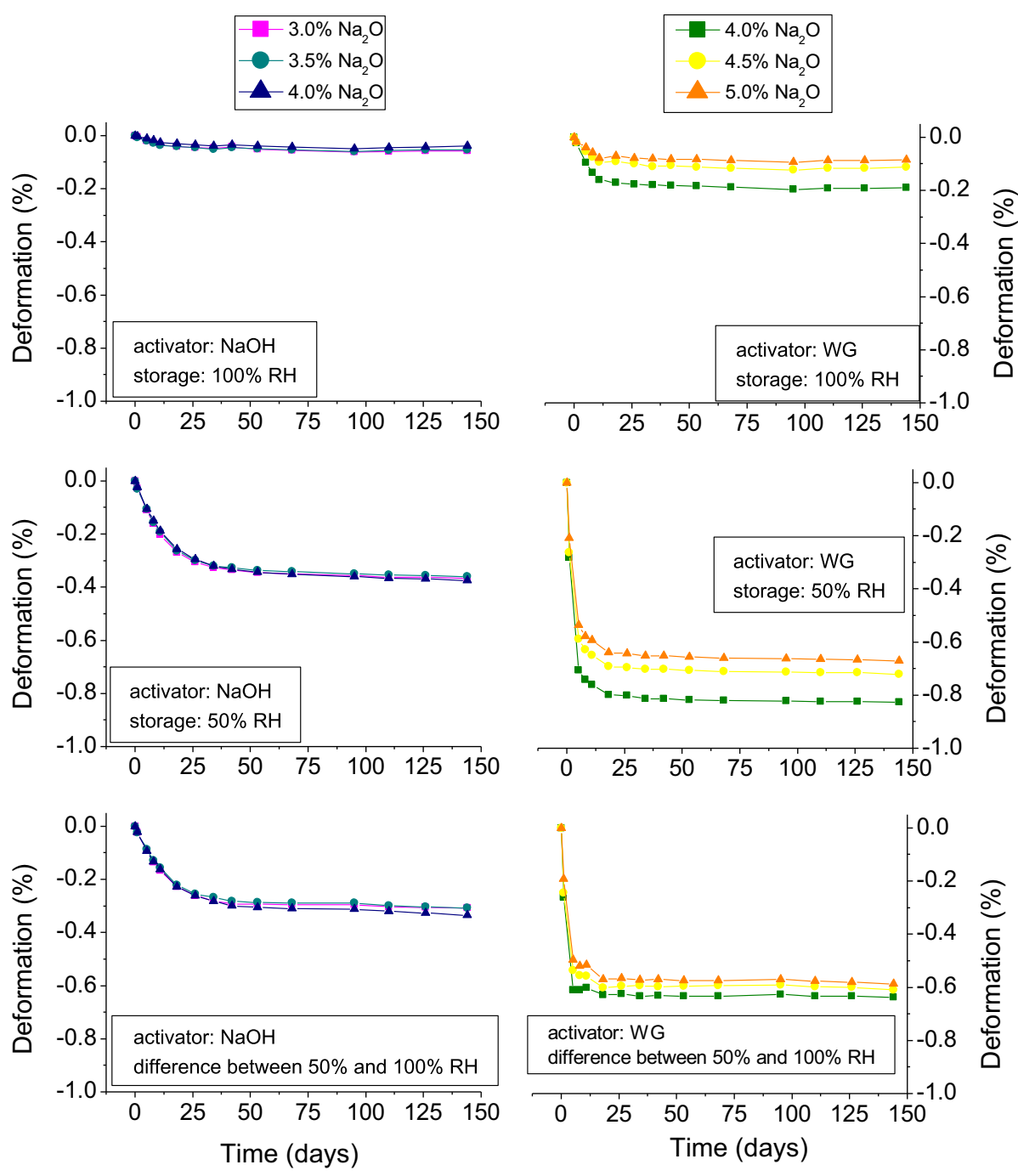

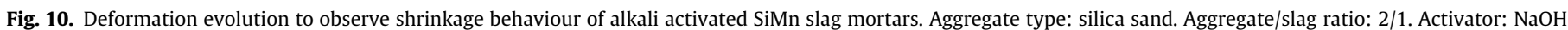
(left), WG (right). Conditioning: 100\% RH (top), 50\% RH (medium), difference between 50\% RH and 100\% RH (bottom).

and aggregate/slag ratio of 2/1 achieved the highest drying shrinkage for all activator concentrations. However, for $\mathrm{NaOH}$ activation, autogenous shrinkage was approximately similar for all types of aggregate, and higher differences could be observed in drying shrinkage. On the other hand, when WG was used as activator, mortars with recycled aggregate showed much higher autogenous shrinkage than the rest of mortars, and mortars with silica sand and aggregate/slag ratio of 2/1 registered again a slightly higher drying shrinkage. These results could be explained by the pore size distributions presented by Fig. 5. As it was previously mentioned, autogenous shrinkage is directly related to the lower diameter porosity. In Fig. 5, in can be noticed that mortars with recycled concrete aggregated presented the higher porosity value in the lower pore diameter range. That fact, in junction with the very low mechanical strength presented by mortars with recycled aggregate at early age would support the much higher autogenous shrinkage of those mortars. On the other hand the low drying shrinkage of mortars with recycled aggregates could be related with its actuation as internal curing agent, since the increase in the $s / s$ that was imposed to meet the workability requirement would act as the pre-saturation step of the aggregates adopted by other researchers [42]. Besides, the higher drying shrinkage that was registered for mortars with silica sand and aggregate/slag ratio of $2 / 1$ could be explained by the denser matrix formed by the that particular mix design which was evidenced by their improved mechan- ical performance. Shrinkage mainly depends on the smallest micropores $(<2.5 \mathrm{~nm})$, but the porosity within that range do not affect mechanical strength, which mainly depends of higher diameter pores $(>10 \mathrm{~nm})$ [38]. Usually, the more efficient the alkali activation process, the higher drying shrinkage it is registered. Finally, the good performance in terms of dimensional stability offered by mortars with silica sand and aggregate/slag ratio of $3 / 1$, could be explained by the higher proportion of inert part, i.e. the aggregate, which would support the low shrinkage registered in spite of their poor mechanical performance. It is widely accepted that a high quantity of aggregates in the mix contribute to the stiffness and dimensional stability of the material, so they help to control the shrinkage.

Finally, it was also observed that the activator concentration did not significantly affect autogenous and drying shrinkage. In addition, the high values of drying shrinkage detected would support the evident need of using shrinkage reducing admixtures for these types of binders, or alternatively, to limit their use in precast elements in which the curing process is much more controlled.

\section{Conclusions}

This work has studied the mechanical performance and dimensional stability of mortars whose binder has been prepared by alkali activation of ground granulated SiMn slag. Solutions of 


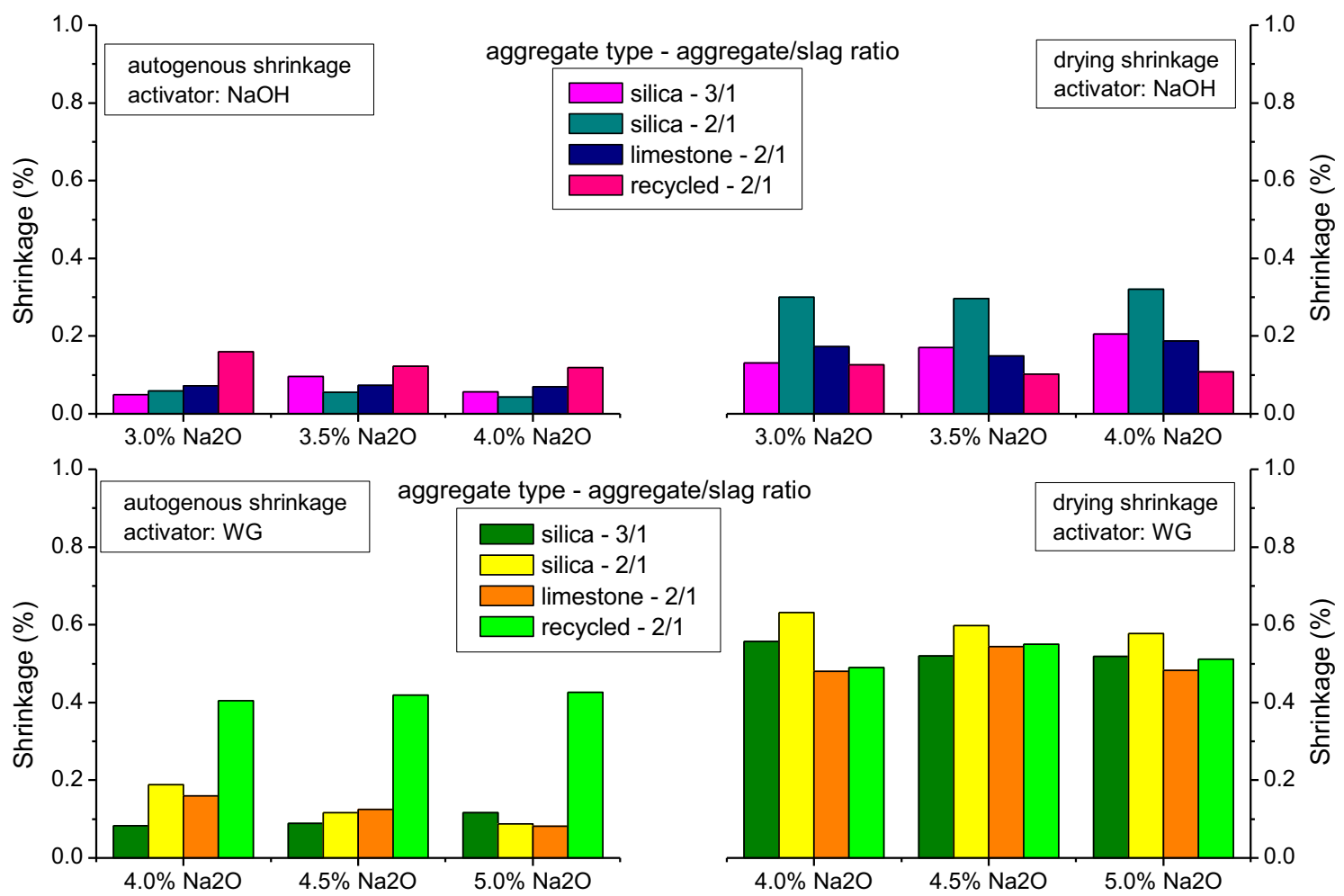

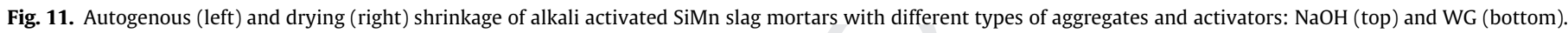

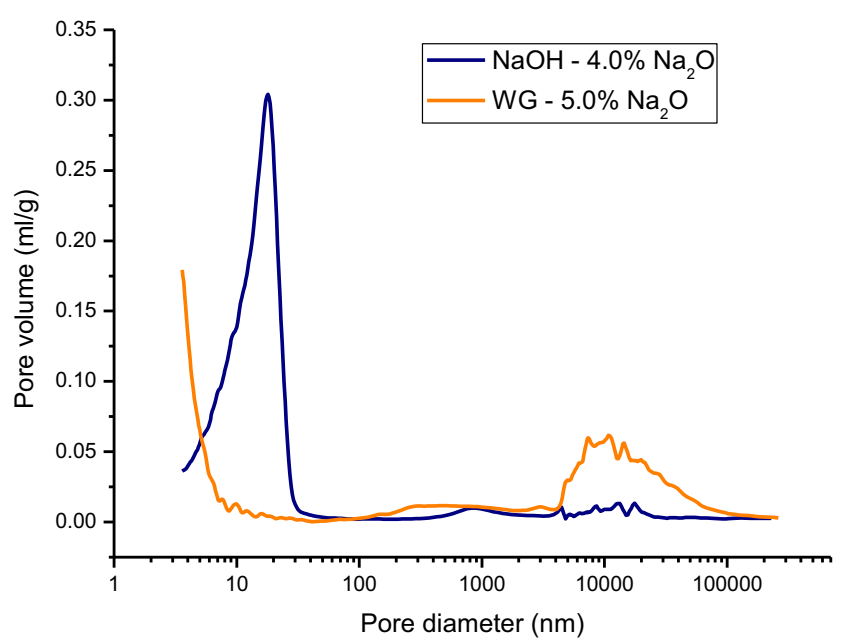

Fig. 12. Pore size distributions of alkali activated SiMn slag pastes at 28 days of curing in $100 \%$ RH ambient.

sodium hydroxide and waterglass have been used activator, and different types of aggregates have been incorporated: silica sand, limestone sand, and recycled sand obtained from recycled concrete. The collected results have concluded that:

1. The best flexural and compressive strength results were obtained for an aggregate/slag ratio of 2/1 when silica sand was used as aggregate, and WG as activator.

2. The mechanical strength provided by recycled concrete aggregate was much lower than the results achieved by silica and limestone aggregates.

3. Higher shrinkage was registered in mortars activated with WG, although autogenous shrinkage was low for all types of activators and aggregates, except for recycled concrete aggregate.
4. The best type of aggregate for mortar preparation was silica sand, although limestone sand also offered a good performance.

\section{Conflict of interest}

None.

\section{Acknowledgements}

The authors wish to thank the Spanish Ministry of Economy and Competitiveness and European Union (FEDER) for project funding (BIA 2014-58194-R). The authors also wish to thank Cristina Rodríguez from Ferroatlántica, S.A., for the supply of SiMn slag necessary to carry out this research; ARECOSUR, S.A., for the supply of the recycled aggregate that has been included in this work; and GIQUIMA research group from the Universitat Politècnica de València for their support in the slag grinding procedures.

\section{References}

[1] C. Shi, A. Fernandez Jimenez, A. Palomo, New cements for the 21st century: the pursuit of an alternative to Portland cement, Cem. Concr. Res. 41 (2011) 750763, https://doi.org/10.1016/j.cemconres.2011.03.016.

[2] M.C.G. Juenger, F. Winnefeld, J.L. Provis, J.H. Ideker, Advances in alternative cementitious binders, Cem. Concr. Res. 41 (2011) 1232-1243, https://doi.org/ 10.1016/j.cemconres.2010.11.012.

[3] K.H. Yang, Y.B. Jung, M.S. Cho, S.H. Tae, Effect of supplementary cementitious materials on reduction of $\mathrm{CO} 2$ emissions from concrete, J. Clean. Prod. 103 (2015) 774-783, https://doi.org/10.1016/j.jclepro.2014.03.018.

[4] J. Vargas, A. Halog, Effective carbon emission reductions from using upgraded fly ash in the cement industry, J. Clean. Prod. 103 (2015) 948-959, https://doi. org/10.1016/j.jclepro.2015.04.136.

[5] Essential Manganese, Int. Manganese Inst. (2016). http://www.manganese.org/ images/uploads/publications/97_16_REPORT-BAT-1.pdf (accessed May 26, 2017).

[6] S. Kumar, P. García-Triñanes, A. Teixeira-Pinto, M. Bao, Development of alkal activated cement from mechanically activated silico-manganese (SiMn) slag, Cem. Concr. Compos. 40 (2013) 7-13, https://doi.org/10.1016/j. cemconcomp.2013.03.026. 
[7] J.L. Provis, A. Palomo, C. Shi, Advances in understanding alkali-activated materials, Cem. Concr. Res. 78 (2015) 110-125, https://doi.org/10.1016/j. cemconres.2015.04.013.

[8] S.K. Nath, S. Kumar, Reaction kinetics, microstructure and strength behavior of alkali activated silico-manganese (SiMn) slag - Fly ash blends, Constr. Build. $\begin{array}{lllll}\text { Mater. } & 147 & \text { (2017) } & 371-379, & \text { https://doi.org/10.1016/ }\end{array}$ j.conbuildmat.2017.04.174.

[9] R. Navarro, E. Zornoza, P. Garcés, I. Sánchez, E.G. Alcocel, Optimization of the alkali activation conditions of ground granulated SiMn slag. Constr. Build. $\begin{array}{lllll}\text { Mater. } & 150 & \text { (2017) } & 781-791, \quad \text { https://doi.org/10.1016/ }\end{array}$ j.conbuildmat.2017.06.064.

[10] S. Akçäzoğlu, C. Ulu, Recycling of waste PET granules as aggregate in alkaliactivated blast furnace slag/metakaolin blends, Constr. Build. Mater. 58 (2014) 31-37, https://doi.org/10.1016/j.conbuildmat.2014.02.011.

[11] B.M. Mithun, M.C. Narasimhan, Performance of alkali activated slag concrete mixes incorporating copper slag as fine aggregate, J. Clean. Prod. 112 (2016) 837-844, https://doi.org/10.1016/j.jclepro.2015.06.026.

[12] A. Wongsa, Y. Zaetang, V. Sata, P. Chindaprasirt, Properties of lightweight fly ash geopolymer concrete containing bottom ash as aggregates, Constr. Build. Mater. $111 \quad$ (2016) 637-643, https://doi.org/10.1016) j.conbuildmat.2016.02.135.

[13] P. Saiz Martínez, M. González Cortina, F. Fernández Martínez, A. Rodríguez Sánchez, Comparative study of three types of fine recycled aggregates from construction and demolition waste (CDW), and their use in masonry mortar fabrication, J. Clean. Prod. 118 (2016) 162-169, https://doi.org/10.1016/j. jclepro.2016.01.059.

[14] A. Arulrajah, A. Mohammadinia, I. Phummiphan, S. Horpibulsuk, W. Samingthong, Stabilization of recycled demolition aggregates by geopolymers comprising calcium carbide residue, fly ash and slag precursors, Constr. Build. Mater. 114 (2016) 864-873, https://doi.org 10.1016/j.conbuildmat.2016.03.150.

[15] F.U.A. Shaikh, Mechanical and durability properties of fly ash geopolymer concrete containing recycled coarse aggregates, Int. J. Sustain. Built Environ. 5 (2016) 277-287, https://doi.org/10.1016/j.ijsbe.2016.05.009.

[16] D.M.A. Huiskes, A. Keulen, Q.L. Yu, H.J.H. Brouwers, Design and performance evaluation of ultra-lightweight geopolymer concrete, Mater. Des. 89 (2016) 516-526, https://doi.org/10.1016/j.matdes.2015.09.167.

[17] Y. Park, A. Abolmaali, Y.H. Kim, M. Ghahremannejad, Compressive strength of fly ash-based geopolymer concrete with crumb rubber partially replacing sand, Constr. Build. Mater. 118 (2016) 43-51, https://doi.org/10.1016/ j.conbuildmat.2016.05.001.

[18] L. Reig, M.A. Sanz, M.V. Borrachero, J. Monzó, L. Soriano, J. Payá, Compressive strength and microstructure of alkali-activated mortars with high ceramic waste content, Ceram. Int. 43 (2017) 13622-13634, https://doi.org/10.1016/j. ceramint.2017.07.072.

[19] C. Neno, J. de Brito, R. Veiga, Using fine recycled concrete aggregate for mortar production, Mater. Res. 17 (2014) 168-177, https://doi.org/10.1590/S151614392013005000164

[20] F. Puertas, R. Santos, M.D.M. Alonso, M. Del Río, Alkali-activated cement mortars containing recycled clay-based construction and demolition waste, Ceram. - Silikaty 59 (2015) 202-210.

[21] J. Péra, J. Ambroise, M. Chabannet, Properties of blast-furnace slags containing high amounts of manganese, Cem. Concr. Res. 29 (1999) 171-177, https://doi. org/10.1016/S0008-8846(98)00096-9.

[22] F. Puertas, Escorias de alto horno : composición y comportamiento hidráulico, Mater. Construcción 43 (1993) 37-48, https://doi.org/10.3989/mc.1993.v43. i229.687.

[23] S.-D.D. Wang, K.L. Scrivener, P.L.L. Pratt, Factors affecting the strength of alkaliactivated slag, Cem. Concr. Res. 24 (1994) 1033-1043, https://doi.org/10.1016/ 0008-8846(94)90026-4.

[24] A.G. De La Torre, S. Bruque, M.A.G. Aranda, Rietveld quantitative amorphous content analysis, J. Appl. Crystallogr. 34 (2001), https://doi.org/10.1107/ S0021889801002485.
[25] UNE 80225:2012. Methods of testing cement. Chemical analysis Determination of reactive $\mathrm{SiO} 2$ content in cements, puzzolanas and fly ash, (2012).

[26] UNE 196-2:2014. Method of testing cement. Part 2: Chemical analysis of cement, (2014)

[27] F. Pacheco-Torgal, J. Castro-Gomes, S. Jalali, Alkali-activated binders: a review. Part 2. About materials and binders manufacture, Constr. Build. Mater. 22 (2008) 1315-1322, https://doi.org/10.1016/j.conbuildmat.2007.03.019.

[28] UNE EN 196-6:2010 Methods of testing cement. Part 6: Determination of fineness, (2010).

[29] E.M. de Fomento, E.C.P. del Hormigón, EHE-08 : Instrucción de hormigón estructural: con comentarios de los miembros de la Comisión Permanente del Hormigón, in: Norm. Instr./Minist. Fom., 2010.

[30] UNE 146301:2002 Aggregates. Fineness modulus of the fine aggregate, 2002.

[31] UNE-EN 1097-6:2014 Tests for mechanical and physical properties of aggregates - Part 6: Determination of particle density and water absorption, 2014.

[32] EN 196-1:2005. Methods of testing cement. Part 1: determination of strength, 2005.

[33] UNE-EN 1015-3:2000/A2:2007 Methods of test for mortar for masonry - Part 3: Determination of consistence of fresh mortar (by flow table), 2007.

[34] UNE 80112:2016 Test methods of cements. Physical analysis. Determination of contraction in air and expansion in water, 2016.

[35] A. Fernandez-Jimenez, F. Puertas, Effect of activator mix on the hydration and strength behaviour of alkali-activated slag cements, Adv. Cem. Res. 15 (2003) 129-136, https://doi.org/10.1680/adcr.15.3.129.36623.

[36] F. Puertas, C. Varga, M.M. Alonso, Rheology of alkali-activated slag pastes. Effect of the nature and concentration of the activating solution, Cem. Concr. Compos. $53 \quad$ (2014) 279-288, https://doi.org/10.1016/j. cemconcomp.2014.07.012.

[37] T. Bakharev, J.G. Sanjayan, Y.B. Cheng, Alkali activation of Australian slag cements, Cem. Concr. Res. 29 (1999) 113-120, https://doi.org/10.1016/S00088846(98)00170-7.

[38] C. Shi, Strength, pore structure and permeability of alkali-activated slag mortars, Cem. Concr. Res. 26 (1996) 1789-1799, https://doi.org/10.1016/ S0008-8846(96)00174-3.

[39] J.L. Provis, P. Duxson, J.S.J. van Deventer, The role of particle technology in developing sustainable construction materials, Adv. Powder Technol. 21 (2010) 2-7, https://doi.org/10.1016/j.apt.2009.10.006.

[40] M.M. Alonso, S. Gismera, M.T. Blanco, M. Lanzón, F. Puertas, Alkali-activated mortars: workability and rheological behaviour, Constr. Build. Mater. 145 (2017) 576-587, https://doi.org/10.1016/j.conbuildmat.2017.04.020.

[41] O. Burciaga-Díaz, M.R. Díaz-Guillén, A.F. Fuentes, J.I. Escalante-Garcia, Mortars of alkali-activated blast furnace slag with high aggregate:binder ratios, Constr. Build. Mater. 44 (2013) 607-614, https://doi.org/10.1016/ j.conbuildmat.2013.03.057.

[42] N.K. Lee, S.Y. Abate, H.-K. Kim, Use of recycled aggregates as internal curing agent for alkali-activated slag system, Constr. Build. Mater. 159 (2018) 286296, https://doi.org/10.1016/J.CONBUILDMAT.2017.10.110.

[43] P. Kathirvel, S.R.M. Kaliyaperumal, Influence of recycled concrete aggregates on the flexural properties of reinforced alkali activated slag concrete, Constr. Build. Mater. 102 (2016) 51-58, https://doi.org/10.1016/J. CONBUILDMAT.2015.10.148.

[44] K. Parthiban, K. Saravana Raja Mohan, Influence of recycled concrete aggregates on the engineering and durability properties of alkali activated slag concrete, Constr. Build. Mater. 133 (2017) 65-72, https://doi.org/10.1016/ J.CONBUILDMAT.2016.12.050.

[45] P. Nuaklong, V. Sata, P. Chindaprasirt, Influence of recycled aggregate on fly ash geopolymer concrete properties, J. Clean. Prod. 112 (2016) 2300-2307, https:// doi.org/10.1016/j.jclepro.2015.10.109.

[46] J.L. Provis, J.S.J. Van Deventer, Alkali Activated Materials : State-of-the-Art Report, RILEM TC 224-AAM, n.d. 